Case Report

\title{
Quality Assurance in Higher Education: Empirical Evidence from Bosnia and Herzegovina
}

\author{
Aleksandra Figurek ${ }^{1}$, Solomon T. Abebe ${ }^{2}$, Anatoliy G. Goncharuk ${ }^{3}$, Enoch T. Iortyom ${ }^{2,4}$, Una Vaskovic ${ }^{5}$, and \\ Giuseppe T. Cirella ${ }^{6, *}$
}

1 Faculty of Agriculture, University of Banja Luka, 78000 Banja Luka, Bosnia and Herzegovina; aleksandra.figurek@agro.unibl.org

2 Polo Centre of Sustainability, Imperia, 18100 Italy; solomtu6@gmail.com

3 Department of Management, International Humanitarian University, 65009 Odessa, Ukraine; agg@ua.fm

4 Department of Geography, Environment and Sustainability Studies, Ernest Bai Koroma, University of Science and Technology, Sierra Leone; etiortyomenoch@ebkustsl.edu.sl

5 Hochschule Macromedia, University of Applied Sciences, 80335 Munich, Germany; vaskovic1997@gmail.com

6 Faculty of Economics, University of Gdansk, Sopot, Poland

* Correspondence: gt.cirella@ug.edu.pl (G.T.C.)

\begin{abstract}
Education is the bedrock of any nation. It is essential for individual and societal growth and development. This triggers the demand for quality education which simultaneously increases with a growing demand for quality assurance. This study investigated the role of quality assurance in achieving the expected outcome of education in Bosnia and Herzegovina's higher education system. Comparative development is looked at by examining other National Qualification Frameworks. The study was based on textual reviews and descriptive analysis on student enrollment and programs of studies. Unlike the global trend, it can be seen that student enrollment is on the decline in Bosnia and Herzegovina. It was found that quality assurance is an indispensable tool for strengthening the higher education system and for achieving the desired change and outcomes, that education offers. It was also found that study programs and curricula are pivotal for teaching and learning processes, and that a unified qualification framework is essential for achieving set objectives of education at all levels. The study recommended, among other things, that sound quality assurance systems as well as appropriate structure for monitoring and accreditation be put in place and be judiciously followed in order to achieve the desired outcomes in conjunction with the set objectives of higher education. Moreover, vital thoroughly analyzed pressures (i.e., democratic, economic, and systemic) barriers show signs of epistemological, political, and institutional barriers in the country.
\end{abstract}

Keywords: National Qualification Framework; education performance; university barriers; education system; Bosnia and Herzegovina

\section{Introduction}

As popularly alluded, education is the bedrock of any nation. It is essential for individual and societal growth and development. Admittedly, World Education Forum [1] and Cuesta et al. [2] averred that education generally plays a critical and reminiscent role in driving economic development the world over. In recognition of this crucial place of education, United Nations Educational, Scientific and Cultural Organization declared a benchmark of at least $26 \%$ of total public expenditure to education [3]. To this effect, most nations attribute a high percentage of their budget to education. Yet, to achieve the goal, the quality of education provided for learners is a major determinant of the expected impact education should create. As a result, the demand for education skyrockets by the day. For instance, the global projection by 2025 shows that the demand for higher education could reach 263 million students [4]. The demand for quality education simultaneously increases with a growing demand for quality assurance for international universities [5]. 
The concept of quality itself is difficult and multidimensional to define [6]. The use of the term quality assurance has changed over time to reflect society's growing interest in evaluating the performance of institutions of higher education - note that different authors define quality assurance in higher education differently [7]. First, there is the category of those that give a broad definition that targets one central goal or outcome [8,9]. Second, there is the category in which through designation of specific indicators desired inputs and outputs are manifested [10-14]. Currently, the suggested use, comprehensively, refers to all of the policies, procedures, and activities that are used to validate and improve the performance of a higher education institution [15]. Moreover, quality has been defined from a stakeholder-driven perspective [15,16]. For instance, Scotland's Credit and Qualification Framework (SCQF) is regarded as a success story in terms of introducing a robust National Qualification Framework (NQF). NQFs consistent of a conceptual model, loose architecture guidelines, and voluntary, partnership-based education. In Europe, their execution are often credited as a baseline for framing education programs continent-wide $[17,18]$. A comprehensive NQF introduces a standardized language and common curriculum across completely different sectors of the education and coaching systems. Area unit tools create a method that is clear and coherent for coordinating framework elements and for constructing pathways between them. At present, NQFs are broadly utilized throughout the European Union and a number of other countries (e.g., Australia and New Zealand) [19]. These countries demonstrate that, over time, problems can build up and require reform; however, once a framework is in situ, any restructuring can be problematic especially with standardized language and the need to educate learners (i.e., students) in a language not spoken in the community or at home [17]. In short, while quality is the desired result, quality assurance is the process through which systems try to ensure that quality is achieved and continuously improved. As with many European countries, English has become a common teaching language, mixed in with programs that also instruct in the native language of the country.

To drive the motivation for this study, it is important to draw out the main objective of quality assurance in higher education. Thus, according to Bobby [16], the main objective of quality assurance in higher education is to support and boost development of higher education institutions which will thereby promote educational achievements. Also, the fact that the quality of an education system depends on its capacity to equip young people with the skills and competences needed for their personal development and fulfillment to function in society, the integration and transition into the labor market is fundamental. This study seeks to provide a comprehensive analysis and overview of how school quality assurance policies, procedures, and practices currently work in Bosnia and Herzegovina's higher education. It examines the processes to advance measures that will enhance the quality of education, i.e., the system currently set in place, via social cohesion, equity, employment, innovation and competitiveness society-wide. A breakdown of the paper is structured as follows: Section 2 explains the materials and methods used in the study; Section 3 elucidates the results and the state of the art and higher educational development in Bosnia and Herzegovina; Section 4 discusses modernization steps for the country's higher education system; and Section 5 pieces together the conclusion and future scope of the research.

\section{Materials and Methods}

2.1. Area of Study

Bosnia and Herzegovina is situated at the central part of the Balkan Peninsula and covers 51,209.2 $\mathrm{km}^{2}$. The country shares borders with Croatia to the north, west, and southwest (i.e., with a border length of $932 \mathrm{~km}$ ), with Serbia to the east (i.e., $357 \mathrm{~km}$ ), and with Montenegro to the southeast (i.e., $249 \mathrm{~km}$ ). Bosnia and Herzegovina consist of two administrative entities namely Federation of Bosnia and Herzegovina (i.e., divided into ten cantons that further is split into 79 municipalities) and Republic Srpska (i.e., divided 
into regions and further into 62 municipalities) and the Brcko District (i.e., a separate district under the government of the state). Economic wise, the gross domestic product of Bosnia and Herzegovina as at 2019 was $2.8 \%$. Specifically, on education, the higher education institutions in Bosnia and Herzegovina include both public and private institutions [19]. The public higher education intuitions are established in accordance with the Framework Law on Higher Education [20], the county's law on higher education for the Federation of Bosnia and Herzegovina, and the Law on Higher Education for the Republic of Srpska [20-22].

\subsection{Research Design}

The study employed a textual analytical approach. This involves reviewing existing literature and studies upon which inferences are made with regard to quality assurance of higher education of Bosnia and Herzegovina. Moreover, secondary data on student enrollment in higher education were sourced from the Statistical Offices and Agencies of Bosnia and Herzegovina, Brcko, and Republic Srpska, and used for descriptive analysis. Comparatively, the study will refer to Scotland's framework as a baseline using the Higher Education Statistics Agency. The analysis, thereof, is largely qualitative in nature - with findings presented as recommendations and ways forward for its higher education development.

\section{Results: State of the Art and Higher Education Development}

3.1. History of Quality Assurance in Bosnia and Herzegovina's Higher Education with comparison to Scotland's system

In 2005, the European Network for Quality Assurance in Higher Education made the first step in setting the process through which systems try to ensure that quality is achieved and continuously improved [20]. This was by establishing widely quality-related values, expectations, good practices, and its assurance by institutions [22]. Concurrently, standards and guidelines are directed in a way that achievements of those are equivalent to implementing the Bologna Process. The Process began in 1999 with allegiance of 29 European governments to carry out complementary higher education reforms in order to set up a 'European Higher Education Area' harmoniously with national systems [19]. Then, the crucial role of the European Commission in supporting the reforms of curricular development, degree structures, credit transfer, and quality assurance which are transforming the European higher education area was announced by the Bergen ministerial conference of the Bologna Process, May 2005.

Bosnia and adopted a new state level Framework Law on Higher Education in 2007 after the signing onto the Bologna Process [20]. The country introduced three cycles of studies with corresponding European Credit Transfer System (ECTS) in credits. Accordingly, Bachelor studies provide 180 or 240 ECTS for three- or four-year programs, respectively; Master studies either 60 or 120 ECTS and Doctor of Philosophy studies provide 180 ECTS. The social aspect was noticeable as a priority of the Bologna Process in which varying European governments articulated giving attention to the social circumstance of the students in their country [22,23].

SCQF, launched in 2001, followed a collection of initiatives beginning in the 1980s that rationalized specific qualifications by developing partial frameworks for unique sectors or stages of learning. The normal pattern in Scotland has been for university students to complete their first degree in a four-year program (i.e., on a full-time basis). An ordinary degree requires a minimum of 180 ECTS of which 30 ECTS should be at SCQF level nine. Specialized degrees require a minimum of 240 ECTS with a 60 ECTS at SCQF level nine and ten (i.e., with a minimum of 45 ECTS at level ten) $[17,18]$. Comparatively, with similar ECTS structure, we can see Bosnia and Herzegovina's implementation of the Bologna Process as an initial step towards entering the European higher educational system. 


\subsubsection{School Enrollment}

This is presented in twofold: (1) general student enrollment in schools (Figure 1) and, comparatively, student enrollment in higher education in Bosnia and Herzegovina and Scotland (Figure 2).

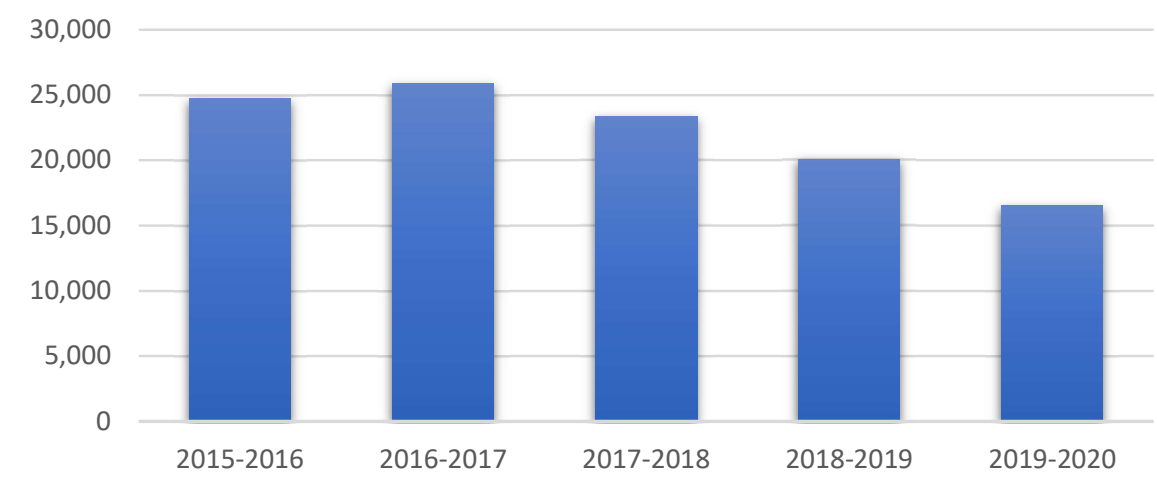

Figure 1. Number of students enrolled in Bosnia and Herzegovina, 2015-2020. Source: Statistical Offices and Agency of Federation of Bosnia and Herzegovina, Brcko, and Republic Srpska.

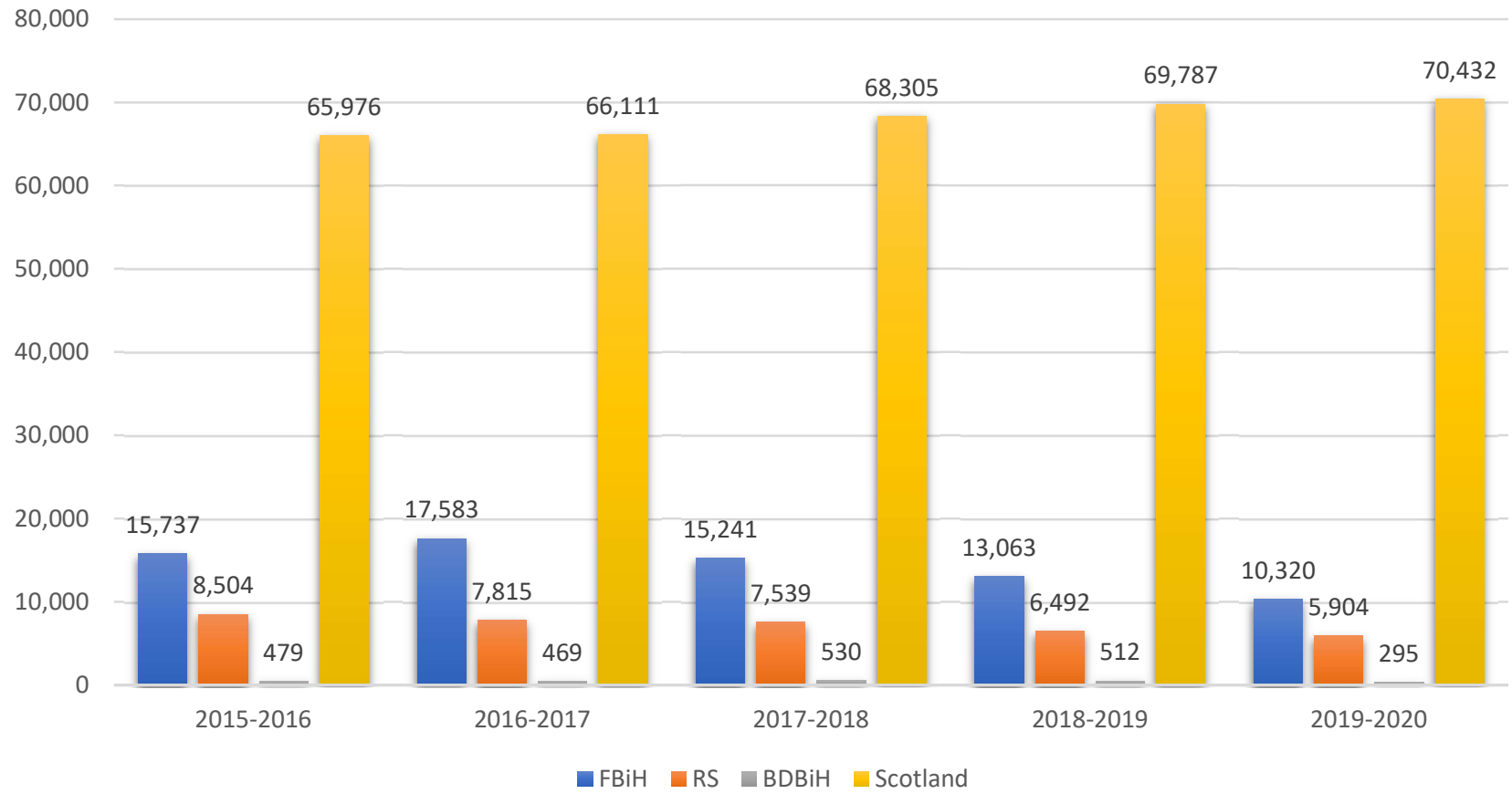

Figure 2. Number of students enrolled for the first time in the first year of study, 2015-2020; FBiH = Federation of Bosnia and Herzegovina, RS = Republic Srpska, and BDBiH = Brčko District. Source: Statistical Offices and Agencies of FBiH, Brcko, and Republic Srpska; Higher Education Statistics Agency, 2019.

\subsubsection{Enrollment in Higher Education}

Student enrollment in higher institution in Bosnia and Herzegovina is presented in Figure 3. This captures study programs by type of ownership and degree level between 2019 and 2020. Specifically, it covers seven private and five public higher education institutions (i.e., by ownership type), as well as Diploma, Bachelors, Master, and Doctor of Philosophy degrees (i.e., by degree level). To further detail the overview of the study 
programs in Bosnia and Herzegovina (Figure 4, top) and Scotland (Figure 4, bottom), abroad field of study is presented in both countries. It both cases, it reveals that programs offered in arts and humanities are higher than the ones offered in other field of studies, while those in services are the least.

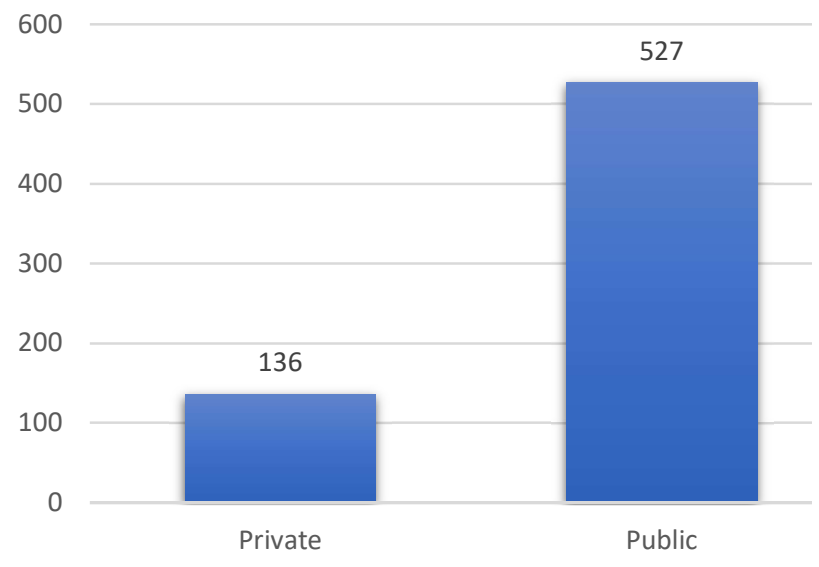

Number of study programs

(a)

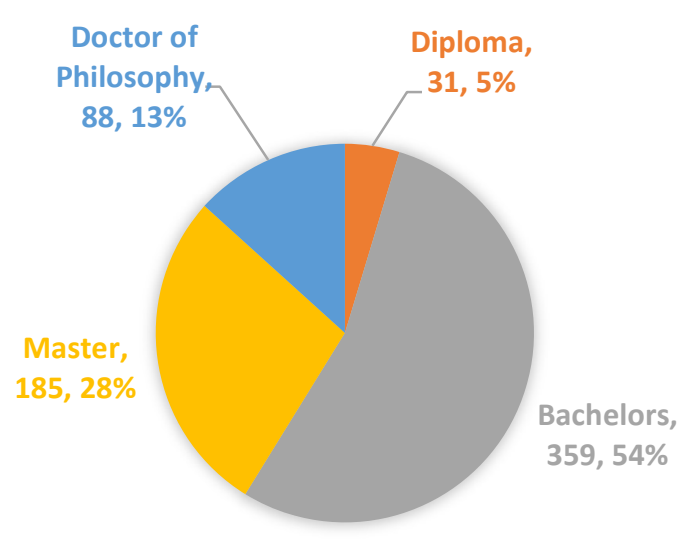

(b)

Figure 3. Study programs by type: (a) ownership and (b) degree level, 2019-2020. Source: HE Provision Database created for a study that covers seven private and five public higher education institutions. 


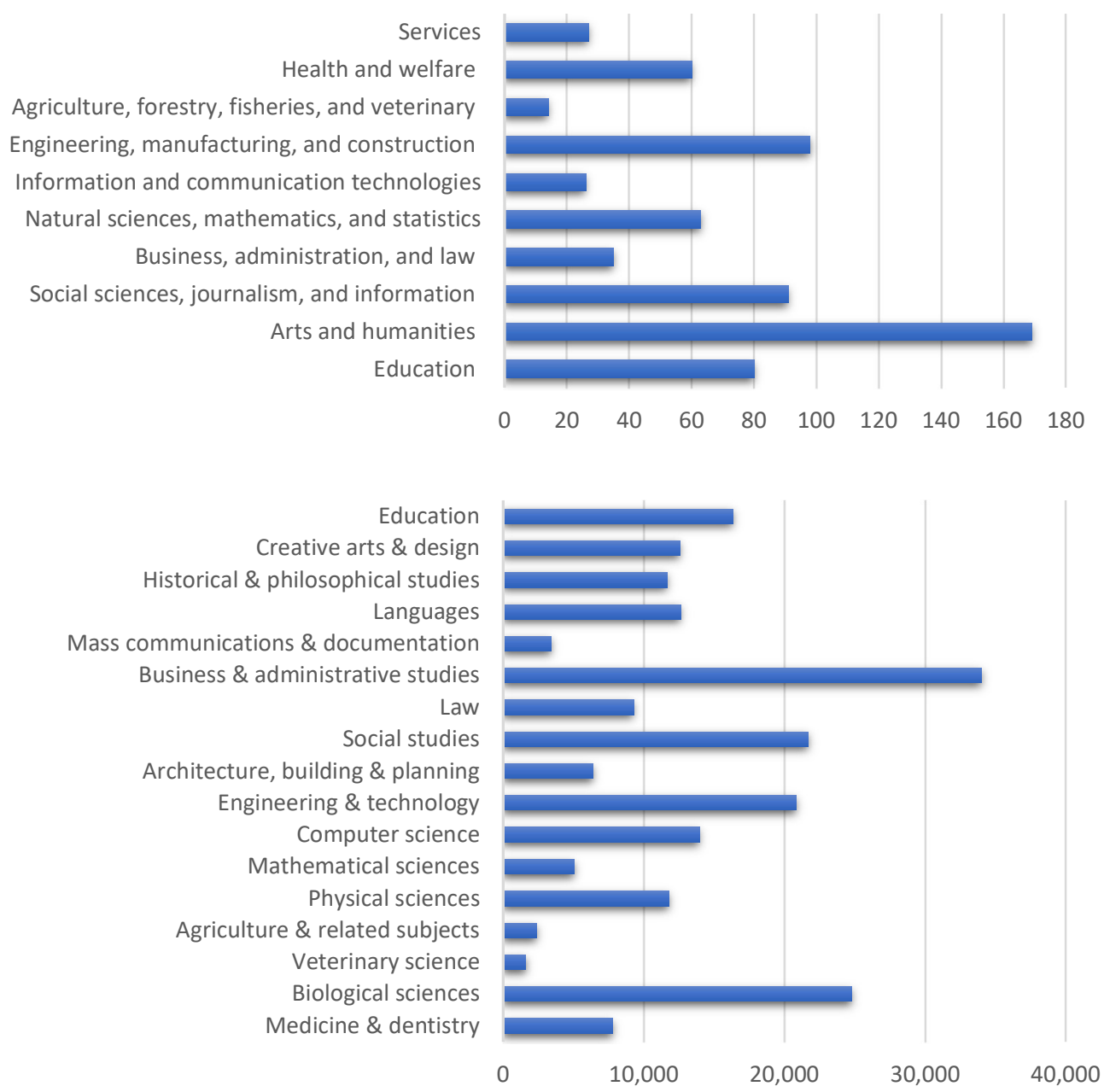

Figure 4. Study programs by broad field of study (top) Bosnia and Herzegovina and (bottom) Scotland for the academic year 2019-2020. Source: HE Provision Database in Bosnia and Herzegovina, 2020; Higher Education Statistics Agency, 2019.

Finally, to further deepen the understanding of the level of quality assurance in higher education institutions, the objectives of the Bosnia and Herzegovina's qualification framework is presented in Figure 5. These objectives, which are the targets that higher education in Bosnia and Herzegovina pursues to achieve, inform the basis for the guidelines required to mapping out a strong enrollment program in the coming decade. The soundness and dexterity of the guidelines as well as commitment toward implementing them sets the country in a positive direction in terms of quality of education. In conjunction, the Joint Council of Europe and European Commission came up with a joint project targeted at strengthening the high education in Bosnia and Herzegovina. The project consists of the basic elements, including; creating a framework for higher education qualifications, development of a work plan for introducing modern procedures and structures for recognition of qualifications, and establishment of standards and guidelines for quality assurance in higher education. Going forward, the proposed guidelines for quality assurance policy in the country and its main objectives are expounded. 
According to the Bosnia and Herzegovina Qualifications Framework, the objectives are:

Creating and maintaining international comparability of standards, especially in the intrainstitutional, inter-institutional, regional, and European context

Avoiding inconsistencies and confusion with the change of higher education qualifications, through a clear description of qualifications in terms of cycles, levels, learning outcomes, and points

Helping higher education institutions, students, and others to clarify the potential pathways of progression and transfer of credits, especially in the context of broader participation in lifelong learning

Facilitating mobility for all (i.e., students, academic, and non-academic staff

Enabling employers, potential students, parents, and others to understand what basic qualification titles are and how qualifications relate to one another

Ensuring that access to and content of higher education is based on the principles and values of a deomcratic soceity

Helping to build domestic and international confidence in higher education qualifications and standards by integrating them with the new quality assurance system, which is fully consistent with the "standards and guidelines" of the European Association for Quality Assurance in Higher Education, European Higer Education Area

Enhancing the recognition of qualifications and employment opportunities by ensuring their relevance to the needs of the domestic and international labor markets

Figure 5. Objectives of the Bosnia and Herzegovina Qualifications Framework. Source: Authors compilation according to the data of the Agency for Development of Higher Education and Quality Assurance of Bosnia and Herzegovina, 2020.

\subsection{Quality Assurance Policy in Bosnia and Herzegovina: Proposed Guideline and Objective}

The quality assurance policies for higher education institutions in Bosnia and Herzegovina are presented in Figure 6. As such, EACEA [26] and Brennan [27] point out that the advancement of the following long-term objectives for a quality assurance system include the following:

- Support equal social opportunities for all learners;

- Support mobility of students, graduates, and citizens within Bosnia and Herzegovina as well as internationally; 
Quality Assurance Policy for Higher Education Institutions

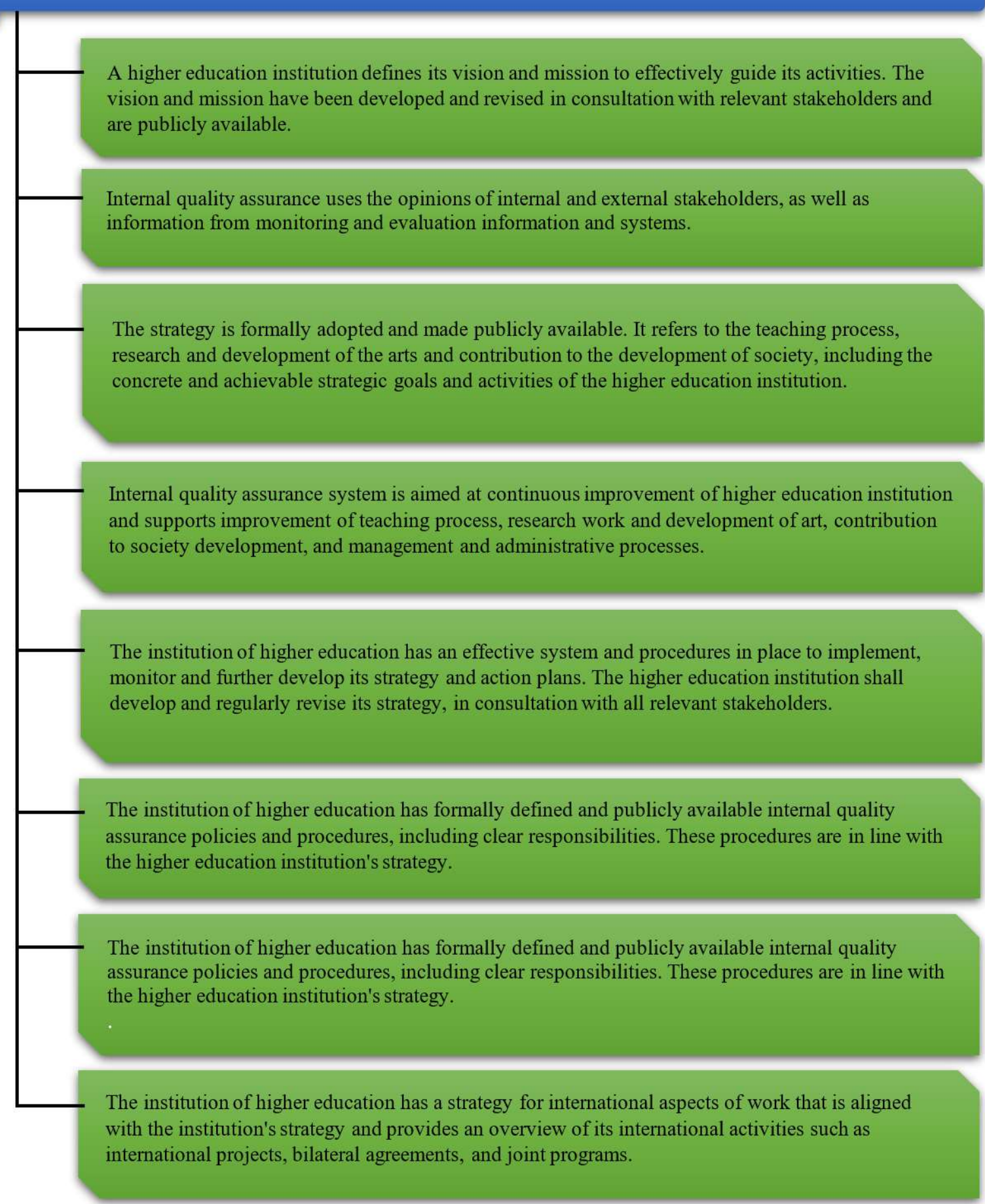

Figure 6. Quality assurance policy of higher education institutions in Bosnia and Herzegovina. Source: Authors compilation according to the data of the Agency for Development of Higher Education and Quality Assurance of Bosnia and Herzegovina, 2020.

- $\quad$ Encourage research and knowledge transfer; 
- Respond to stakeholder and user needs in higher education;

- Guarantee comparability with the European Union across a wide range of areas (e.g., student learning support network and graduates and employer feedback systems); and

- Improve the public accountability of higher education to the wider society.

The importance of maintaining quality assurance is to ensure that the expected outcome of education programs is achievable. In this regard, internal guidelines may not be sufficient to maintain and achieve this desired target. This brings to light the need for external quality assurance strategy that will monitor and stir the system towards achieving the set objective for qualitative education. Affirmatively, Stensaker [28] noted that external quality assurance is of immense importance. The study, therefore, presents accreditation and accreditation system which dwells on the external quality assurance system.

\subsection{Introduction of Accreditation and its Systemization}

According to Patricia [29], the Council for Higher Education Accreditation advanced three important factors that influence the quality assurance trends in international higher education. First, increment in competitiveness and rigorousness of quality assurance. Second, quality assurance that has been recognized regionally. Third, demand for an international quality assurance framework [29]. However, studies in both developing and developed countries outlined a challenge in the accreditation process are subject to manipulation and abuse in relation with local accrediting agency [30-32]. Two sets of criteria for conducting accreditation include the criteria for accreditation of higher education institutions in Bosnia and Herzegovina and the criteria for accreditation of study programs I and II cycles [2]. The criteria for accreditation of higher education institutions, and study programs in Bosnia and Herzegovina expanded with guidelines for internationalization pursues such things as:

- Encouraging and supporting continuous improvement in the quality and standards for the provision of higher education programs;

- Guaranteeing that clear and accurate information is made publicly available about the quality and standards of higher education and training provision; and

- Placing international best practice in evaluation and reviews of higher education and train [33].

Also, on the importance of external quality assurance, four key forms, i.e., structures, are identified from the studies of Stensaker [28], Palmer [34], Kis [35] and Lange [36]: accreditation, audit, assessment, and licensing. The process is structured in a fourstep model, as outlined:

(1) Self-review report-must be submitted by the institution under review in order to provide its own analytical view;

(2) External review team-should encompass three to five persons of high academic standing and repute, competent to make national and international comparisons on the quality of teaching and research and the provision of other services at university level;

(3) Review team - must visit the institution in order to confirm the self-review report;

(4) Review team should submit the evaluation report in a timely manner-this report along with the conclusions and recommendations must be made publicly available.

Indicators can be performance, as noted by Suryadi [37], and qualitatively assessed according to Chalmers [38] which are adequate to valorize the implementation of this standard can be seen through implemented protocols (Figure 7). This is consistent with the use of the four-step review model, i.e., by reporting on self-evaluation, published, and consistently applied criteria, for nomination of external quality assurance experts 
via the provision of appropriate briefing or training. This will include training of experts, program development, and documentation on accreditation design, either planned or realized, e.g., via the use of international experts and the participation of students.

For each program of study documented evidence should be produced in order to properly implement the following concerns

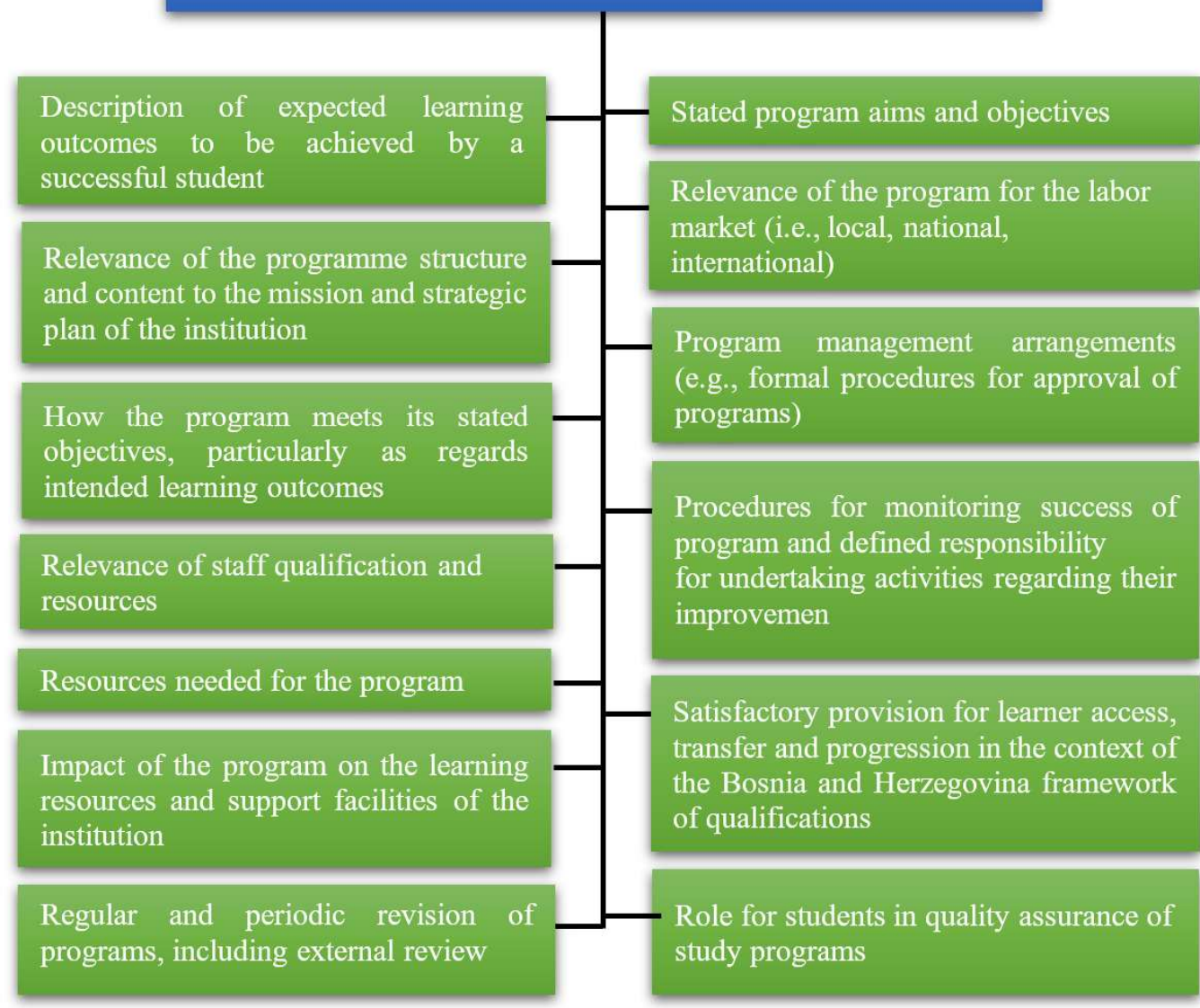

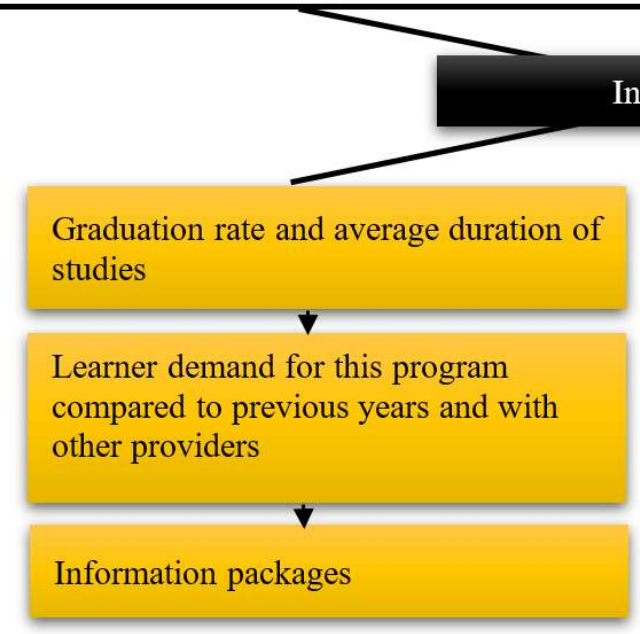

Indicators

Figure 7. Key elements of the study programs and their indicators. 
Study program quality assurance policy defined the following, i.e., next-level, rules:

- Higher education institution has an approved and publicly available policy of internal security of the quality of study programs as well as its strategic management;

- Policy of ensuring the quality of study programs is aimed at promoting, i.e., research work, learning and teaching, mobility, and internationalization on study programs, as well as preventing plagiarism of teachers' work and students' final work on all study cycles; and

- $\quad$ Policy supports the development of a quality culture in which all internal participants contribute to the quality of study programs, and defines the way in which external participants are involved in it.

\subsection{Stylized Facts: A Shift in Thinking}

Education organizational structure in Bosnia and Herzegovina is complex. The legislation and education policy comprise of many administrative levels that greatly complicate the education system and make it difficult to apply the Bologna Process at the same level throughout the country [39]. For the educational sector, for instance, the authority has been delegated to the ten cantons of the Federation of Bosnia and Herzegovina, Republic Srpska, and the Brčko District, each with a ministry of education responsible for the organizational and functioning of the education system. Each administration has its own laws in the area of education and educational budget. Moreover, each have the right to determine the education policy and all other rights and responsibilities arising from the mandate of the capable education authority responsible for the organization and functioning of education.

Only four European countries had quality assurance agencies prior 2000 [40], while the number of countries having this agency has reached to 23 in 2019 [41]. Agency for Development of Higher Education and Quality Assurance was established in 2008 in order to make uniform rules in the high educational sector. The aim of the Agency for Development of Higher Education and Quality Assurance is defined through the following (noteworthy) points:

- Determination of clear, transparent, and accessible criteria for accreditation of higher education institutions and passing of norms determining the minimum standards in the area of higher education;

- Determination of the criteria for the selection of domestic and international experts who provide evaluation and perform the quality review and provide recommendations on accreditation of higher education institution;

- Provision of recommendations on the criteria and standards to the Ministry of Republic Srpska, cantonal ministries, and the Brcko District for establishing and closing higher education institutions, and for restructuring study programs; and

- $\quad$ Provision of advice on the work and development policy to the Ministry of Republic Srpska, cantonal ministries, and the Brcko District.

Strategic elements for the development of study programs in Bosnia and Herzegovina also defined professional development of academic staff. The decision makers in educational sector and universities plan and implement training and use of information and communication technology in education as well as acknowledge of foreign languages as conditions for internationalization of and mobility in the education sphere. Participation in training program at the national and international levels is one of the elements for the promotion and advancement related to the scientific-educational titles. Also, internationalization is frequently mixed up with globalization [42]. By achieving a more efficient functioning of higher education institutions or study programs, it is also possible to achieve through strengthening internationalization [42]. This opens up new opportunities for patronage and cooperation with different European institutions, and provides access to various international funds. 
Globally, higher education institutions have been behaving simultaneously on subjects of competition and cooperation $[43,44]$ through internationalization, which has become a global remarkable development [45]. Many scholars emphasize its need to develop a quality culture simultaneously, addressing the challenges of globalized higher education $[42,46,47]$. Moreover, many countries generate a significant amount of revenue from international students by charging high fees and spend significant amounts of money in the host countries - for instance, it is estimated that over USD 12 billion accrues to the American economy annually [48]. On this note, for more than two decades, the European Union actively followed academic internationalization as part of the move to political and economic desegregation, though others like Connor [49] are more doubtful that mobility contributes in significant measure to integration through encouraging and funding programs such as Erasmus that provided students with academic involvements outside their home country [50]. The internationalization of education is an integral part of all policy documents of Bosnia and Herzegovina at national and institutional level. MurphyLejeune [51] highlighted that one way of improving the university up to an excellent level is to use internationalization strategies effectively.

The following are aims of internationalizing the education system. First, improving regional and cross-border cooperation through joint participation. Second, actively supporting the international mobility of student and staff. Third, supporting the development of study programs in foreign languages. Fourth, providing training in foreign languages to students and staff in higher education institutions. Finally, developing and funding programs to gain experience abroad for graduates in the field of growth and innovation. Moreover, higher education institutions in Bosnia and Herzegovina signed the Erasmus Agreement in June 2014 which replaced all previous programs during 2007-2013. The previous programs were Lifelong Learning Program, Youth in Action, Erasmus Mundus, Tempus, and Alfa Edulink. Students from Bosnia and Herzegovina are also included in various mobility programs, including: Erasmus Mundus, CEEPUS, MEVLANA, UNET networks as well as a number of institutional bilateral agreements. There are many debates of how Erasmus affects the personal development [52] and if these qualities are socially desirable [53]. At present, universities that have already established networks are via:

- $\quad$ BASILUES - Erasmus Mundus Action II project funded by the European Commission (i.e., consortium consists of ten European Union universities and ten universities in the Western Balkans);

- $\quad$ GreenTech-Smart and Green Technologies for Innovative and Sustainable Societies in Western Balkans;

- $\quad$ EU-SEE-Participating, Exchanging, and Networking in a Transnational Alliance for Internationalization in Higher Education, a scholarship scheme for mobility between the European Union and the Western Balkans;

- $\quad$ SIGMA A-Erasmus Mundus Action II project within the European Commission scholarship program Erasmus Mundus Action 2, Strand 1, Lot 2, Western Balkans;

- $\quad$ ERAWEB (ERASMUS-WESTERN BALKANS) - joint mobility program offered by eight Western Balkan universities, of which is made up of the University of Sarajevo and six European Union universities;

- EUROWEB-European Research and Educational Collaboration with Western Balkans;

- $\quad$ STEM-Erasmus Mundus project enabling the exchange of staff and students across higher education institutions and fostering entrepreneurship and management skills in science, technology, engineering, and mathematics; and

- $\quad$ SUNBEAM - structured university mobility between the Balkans and Europe for the Adriatic-Ionian Macro-region. 
Moreover, Bosnia and Herzegovina is a member of South East European Centre for Entrepreneurial Learning, European Centre for Modern Languages of the Council of Europe, Bologna Follow-Up Group, Education Reform Initiative of South Eastern Europe, and other international organizations in the field of education. More than 150 Joint Erasmus Mundus Master and 40 joint Doctor of Philosophy programs were available for students under Erasmus Mundus Action I. All these programs led towards joint or multiple diplomas. During the past seven years, about 70 students from Bosnia and Herzegovina were granted scholarships to follow Erasmus Mundus joint Master and Doctor of Philosophy courses at high-status European Union universities [54]. Since 2007, Bosnia and Herzegovina has been involved in the CEEPUS-III network, which has provided up to now more than EURO 76,000 monthly scholarships for mobility in sixteen European countries participating in the program [54].

Recently, Popa [39] shows that the existence of impediments in Bosnia and Herzegovina education systems for implementing the Bologna Process, particularly mobility of students and academic staff, is still at a very low level, i.e., locally, regionally, and internationally. SWOT analysis by Popa [39] shows partial adaptation of curricula, teaching, and learning methods as well as research in relation to the European level as inappropriately harmonization at the policy level. As Jones [56] and United Nations Economic Commission for Europe [57] outlined, it will also be significant for an internationalization to be responsible, effective, ethical, and sustainable. The following are three examples of some of the vital issues, in this respect: (1) understand internationalization is not a goal by itself, (2) make certain that no single approach or paradigm is predominant, but consider it as a comprehensive policy process, and (3) realize improved linkages between internationalization and multiculturalism.

\section{Discussion}

From Figure 2, the result outlined a 4.64\% increment of enrollment in 2016-2017 compared with the previous academic session (i.e., 2015-2016). However, consistent decline occurred in the subsequent sessions per year. In 2017-2018's academic year, for instance, the number of students enrolled decreased by $10 \%$ compared to the previous academic year. In the following years, the declining percentage increased to $14 \%$ and to $18 \%$ compared to the previous. In the last three years, the number of students enrolled for the first time in the first year of study dropped by $29 \%$, i.e., from 23,310 to 16,519 . In other words, while global demand for higher education was on the increase, for instance in Scotland, and projected to reach 263 million students (i.e., about 163 million increase in the next 25 years), it can be seen from this study that student enrollment is on the decline in Bosnia and Herzegovina [58,59]. Similarly, this corresponds with a $20.7 \%$ rate of unemployment of young people [58], while the World Bank [60] reports a higher rate, i.e., 46.7\% - corresponding with the lack of practical teaching and a system connected with poor linkage with the labor market creating an inability to integrate graduates with post-study life. In fact, the tremendous engagement of private enterprises has been a challenge for most countries, and NQFs have had solely constrained success in addressing it. Even in relatively well-established frameworks, such as in Scotland and Ireland, employers have been hard to engage [61-63]. Countries such as Turkey and Russia where employers have led NQF developments, most employer engagement with NQFs have been limited and uneven throughout sectors [64]. Figure 3 identifies 527 and 136 study programs in public and private higher education institutions, respectively across all the four-degree levels. These summed up to 664 study programs, of which 31 represent $5 \%$ at the diploma level, 359 represent 54\% at the Bachelor degree level, 185 (i.e., 28\%) at Master degree level, and 88 (i.e., 13\%) at the Doctor of Philosophy degree level. These statistics depicts that most (i.e., over half) of these study programs are offered at the Bachelor, i.e., undergraduate, degree level. The implication of the findings identifies key factors that affected and reduced the number of students enrolled. Deduced from the reviews are two factors; first, is the need 
for higher education institutions to focus on internal quality assurance (i.e., with established criteria) in the work processes-especially in the quality of the study programs. Second, the need for students to be encouraged to thoroughly and critically study curricula that do not view education solely as a pathway to secure work in the public sector, but as something that contributes to improving their lives and the society as a whole.

More so, a special problem for young people in Bosnia and Herzegovina is the procedure and qualification of higher education acquired for continuing education and for recognized professional employment. For example, according to the Ministry of Civil Affairs, the age group of 15 to 30 is categorized as young people. There are 777,000 young people in the country (down by 315,000 from 1,091,775 in 1991). The evidence from 2016's census data indicates that from a total of 722,311 young people aged 15-29 only 95,048 $(13.15 \%)$ have a university degree, and 58.33\% have completed secondary education [58]. According to the World Bank [60], high levels of unemployment is associated to youth (i.e., ages 15-24) and emigration of people in the age bracket is high. Still on this note, the Council of Ministers decided to adopt the Baseline of Qualifications Framework on 24 March 2011 [65] that established the process of building the Qualification Framework at all levels of education by harmonizing with the European Qualification Framework. The Qualification Framework is a methodology tool for the development and provision of occupational standards, qualifications, knowledge, and education based on learning outcomes. The Bosnia and Herzegovina framing of high education institutions defined also the status of higher education institutions as universities as well as professional colleges. Universities organize teaching and research activities and provide academic degrees in three cycles - offering a minimum of five study programs in at least three different subject areas. On the other hand, professional colleges provide degrees in the first cycle for at least one study program and one subject area. Both models of higher education studies (i.e., 3+2 and 4+1) might also be available in some universities. This can complicate student progression, for those that finished a 3-year Bachelor degree and wish to continue at different higher education institutions that only offers a 1-year Master degree and have to complete an additional year of studies to obtain the necessary ECTS credits. It is worthy to note that the Scottish Standard Grading system "Assessment for All" that was introduced in 1984 [66]. Standard Grades are subject-based classes that span the last two years of compulsory schooling (i.e., ages 14-16) and contribute to qualifications that almost any student can pursue. Every subject has three levels of instruction (i.e., foundation, general, and credit) and classes are often designed to train students for two adjacent levels, acting as a "safety net" for those who fail at the higher level.

Before accepting the Bologna Process, the universities in Bosnia and Herzegovina worked on the establishing the quality assurance policies and practices. Quality assurance policies are very important for the development of the higher education sector and, of course, for the inclusion in the European Higher Education Area. This process presented a couple of important issues, which needed to be addressed through systematic assurance procedures. They defined academic, governance, and administrative areas as the crucial points and noteworthy recommendations for the modernization and reform of the higher education sector in the country. However, lesson from Scotland showed that the desire of central authorities to increase their control of education systems and to strengthen the systems' coherence and coordination is strong driver for the change. While economic pressures might also have encouraged the development of an NQF, they cannot be said to be the main driver.

\section{Conclusions}

It can be found from this study that quality assurance is an indispensable strategy for strengthening higher education system and for achieving the desired change and outcomes that education offers. Also, it can be said from the research that study programs and curricula are pivotal for teaching and learning processes, and are a basis by which knowledge is transferred to the younger generation. From the research exponent, it can 
also be noted that a unified qualification framework is essential for achieving set objectives of education at all levels. It can, therefore, be recommended that sound quality assurance systems be put in place and be judiciously followed. They should be adequate and appropriate structured for time-to-time monitoring and accreditation. This will guarantee the achievement of desired outcomes and set objectives of higher education institutions without deviations.

In addition, qualification framework should be set based on the peculiarities in Bosnia and Herzegovina while also taking into cognizance the global best practice in this respect. However, it is vital to analyze pressures (i.e., democratic, economic, and systemic), barriers in relation to epistemological, political, and institutional barriers of a country. Since the study programs and curricula are core for appropriate teaching and learning processes, and knowledge transfer, higher education institutions therefore should ensure that curricula are updated, relevant, adhered, monitored, and improved on a regular basis. Further, students should be made to understand why certain courses and curricula are important or relevant, what different modules will contain, and what they can expect to have achieved at the end of their course and program. This baseline approach, as in Scotland, will assist in producing interest and commitment on the part of the instructors and learners, respectively.

Supplementary Materials: Not applicable.

Author Contributions: Conceptualization, A.F. and A.G.G.; methodology, validation, formal analysis, investigation, A.F., A.G.G., U.V., S.T.A.; resources, data curation, E.T.I.; writing - original draft preparation, A.F., A.G.G., U.V.; writing - review and editing, visualization, E.T.I., S.T.A, G.T.C.; supervision, project administration, G.T.C.; funding acquisition, A.G.G., G.T.C. All authors have read and agreed to the published version of the manuscript

Funding: This research received no external funding.

Institutional Review Board Statement: Not applicable.

Informed Consent Statement: Not applicable.

Data Availability Statement: All the data has been presented in the paper.

Acknowledgments: The authors are grateful to the Polo Centre of Sustainability for supporting this research.

Conflicts of Interest: The authors declare no conflict of interest

\section{References}

1. World Education Forum: Equitable and Inclusive Quality Education and Lifelong Learning for All by 2030. Transforming Lives Through Education., Incheon, Republic of Korea (2015)

2. Cuesta, A., Glewwe, P., Krause, B.: School Infrastructure and Educational Outcomes: A Literature Review, with Special Reference to Latin America. Available from: http://www.pglewwe@umn.edu. (2015)

3. UNICEF: The Children Education UNICEF Nigeria Information Sheet: Girls' Education., Nigeria Country Office, Abuja: Nigeria Country Office. (2015)

4. Karaim, R.: Expanding higher education. CQ Global Researcher 5(22), 525-572 (2011)

5. Hou, A.: Mutual recognition of quality assurance decisions on higher education institutions in three regions: A lesson for Asia. Higher Education 64(6), 911-926 (2012) http://dx.doi.org/10.1007/s10734012-9536-1.

6. De Ketele, J.M.: The social relevance of higher education. In Global University Network for Innovation (GUNi) Report on Higher Education in the World 3. Palgrave, London, UK (2008)

7. Williams, P.: Quality assurance: friend or Foe? In Robert, B., \& Observatory of the Magna Charta Universitatum Observatory Magna Charter Universitatum (eds.). Contemporary Threats and Opportunities. In: Quality Assurance and Rankings. Proceedings of the Conference of the Magna Charta Observatory. (2011)

8. Bogue, G.: Quality Assurance in Higher Education: The Evolution of Systems and Design Ideals. New Directions for Institutional Research 99, 7-18 (1998) http://dx.doi.org/10.1002/ir.9901.

9. Harvey, L.: Defining Quality. Assessment \& Evaluation in Higher Education 18(1), 9-34 (1993) http://dx.doi.org/10.1080/026029393018010218(1), 9-34. http://dx.doi.org/10.1080/0260293930180102.

10. Barker, K.: Canadian Recommended E-learning Guidelines., Vancouver, BC: FuturEdCanadian Association for Community Education and Office of Learning Technologies, HRDC. (2002) 
11. Lagrosen, S.: Examination of the Dimensions of Quality in Higher Education. Quality Assurance in Education 12(2), 61-69 (2004) http://dx.doi.org/10.1108/09684880410536431.

12. Scott, G.: University Student Engagement and Satisfaction with Learning and Teaching. University of Western Sydney, Sydney (2008)

13. Tam, M.: Measuring Quality and Performance in Higher Education. Quality in Higher Education 7(1), 47-54 (2010) http://dx.doi.org/10.1080/13538320120045076.

14. Vlasceanu, L.: Quality Assurance and Accreditation: A Glossary of Basic Terms and Definitions., Bucharest (2007)

15. Harvey, L.: A History and Critique of Quality Evaluation in the UK. Quality Assurance in Education 13(4), 263-276 (2011) http://dx.doi.org/10.1108/09684880510700608.

16. Bobby, C.L.: The ABCS of Building Quality Cultures for Education in a Global World. In: Paper presented at the International Conference on Quality Assurance, Thailand (2014)

17. Gallacher, J., Toman, N., Caldwell, J., Raffe, D., Edwards, R.: Evaluation of the Impact of the Scottish Credit and Qualifications Framework (SCQF), Edinburgh, Scottish Executive (2005)

18. Young, M.: National Qualifications Frameworks; their feasibility and effective implementation in developing countries. Skills Working Paper 22, Geneva, International Labour Organization (2005)

19. Wheelahan, L.: From old to new: The Australian Qualifications Framework. In Learning from the first five qualifications frameworks, ed. ILO, 91-138. Employment Working Paper 45. Geneva: ILO (2009)

20. Kostic M.J.: Perspectives on and Obstacles to the Internal Reporting Reform at Higher Education Institutions - Case of Bosnia and Herzegovina, Croatia and Slovenia. Journal of Contemporary Management Issues 22(Special issue), 129-143 (2017)

21. Rastoder Aldina, N.: Perceptions of Students towards Quality of Services at Private Higher Education Institution in Bosnia and Herzegovina. European Researcher Series A Vol.101 (12) (2015)

22. Bologna Declaration: European Ministers of Education, Bologna (1999)

23. Ferencz, I: The European Higher Education Area (2015) DOI 10.1007/978-3-319-20877-0_3.

24. Bijnens, H.: European Cooperation in Education through Virtual Mobility: A Best-Practice Manual. Eurospace (2006) Retrieved from http://www.virtualschoolsandcolleges.eu/images/9/9b/BM_handbook_final.pdf.

25. EACEA: The European Higher Education Area in 2015: Bologna Process Implementation Report., European Commission/ Eurydice, Luxembourg (2015)

26. Dill, D.: Through Deming's Eyes: A Cross-National Analysis of Quality Assurance Policies in Higher Education. Quality in Higher Education 1 (1), 95-110 (1995)

27. Brennan, J.: Managing Quality in Higher Education: An International Perspective on Institutional Assessment and Change. SRHE/Open University Press., Buckingham (2000)

28. Stensaker, B.: Accreditation of Higher Education in Europe - Moving towards the US-Model?. Journal of Educational Policy 26 (6), 757-769 (2011)

29. Patricia, R.: Quality Assurance in Higher Education: A Review of Literature. Research Communication 5(4) (2015)

30. Alderman, G.: Can Quality Assurance Survive the Market? Accreditation and Audit at the Crossroads. Higher Education Quarterly 59(4), 313-328 (2005)

31. Blackmur, D.: A Critical Analysis of the UNESCO/OECD Guidelines for Quality Provision of Cross-Border Higher Education. 13 (2), Quality in Higher Education (2007)

32. Goodlad, J.: Teachers for Our Nation's Schools. Jossey-Bass., San Francisco, CA (1990)

33. EU: Standards and Guidelines for Quality Assurance in Higher Education in Bosnia and Herzegovina. (2007)

34. Palmer, N.: Scope, Transparency, and Style: System Level Quality Strategies and the Student Experience in Australia. In External Quality Audit. Has it Improved Quality Assurance in Universities? Chandos Publishing, Oxford (2013)

35. Kis, V.: Quality Assurance in Tertiary Education: Current Practices in OECD Countries and a Literature Review on Potential Effects., OECD, Paris (2005)

36. Lange, L.: External Quality Audits in South African Higher Education: Goals, Outcomes and Challenges. In External Quality Audit. Has it Improved Quality Assurance in Universities?. Chandos Publishing., Oxford (2013)

37. Suryadi, K.: Key Performance Indicators Measurement Model Based on Analytic Hierarchy Process and Trend-Comparative Dimension in Higher Education Institution. In: In Proceedings of the 9th International Symposium on the Analytic Hierarchy Process for Multi-criteria Decision Making (ISAHP), Viña del Mar, Chile, p.2-6 (2007)

38. Chalmers, D.: Teaching and Learning Quality Indicators in Australian Universities.. In: In Proceedings of the Institutional Management in Higher Education (IMHE) Conference, Paris, France (2008)

39. Popa D.: Academic Mobility Policies in Higher Education of Bosnia and Herzegovina. Journal of Pedagogy 1, 159 - 171 (2018) https://doi.org/10.26755/revped/2018.1/159.

40. Loukkola, T.: In EUA, European University Association, A Twenty-Year Contribution to Institutional Change., European University Association, Brussels, Belgium (2014)

41. ENQA: Standards and Guidelines for Quality Assurance in the European Higher Education Area. (2005) http://www.enqa.eu/files/BergenReport210205.pdf.

42. Altbach, P.: Trends in Global Higher Education: Tracking an Academic Revolution., UNESCO Report (2009)

43. Peterson, P.: Diplomacy and education: A Changing Global Landscape.. International Higher Education 2-3., 75 (2014) 
44. Vidovic, H.: SEE 2020 Strategy Study on Labour Mobility., The Vienna Institute for International Economic Studies (2015) Retrieved from https://wiiw.ac.at/ see-2020-strategy-study-on-labour-mobility-dlp-3662.pdf.

45. de Wit, H.: Europe's 25 Years of Internationalization., International Higher Education (2014) 74.

46. Smidt, H.: European Quality Assurance-A European Higher Education Area Success Story [Overview Paper]. The European Higher Education Area: Between Critical Reflections and Future Policies. Springer Open, 625-637 (2015) http://dx.doi.org/.

47. Kosmützky, A.: Transcending Borders and Traversing Boundaries: A Systematic Review of the Literature on Transnational, Offshore, Cross-Border, and Borderless Higher Education. Journal of Studies in International Education 20(1), 8-33. (2016)

48. Davis, T.: Atlas of Student Mobility., Institute of International Education., New York (2003)

49. Connor, W.: Nation-Building or Nation-Destroying? World Politics 24 (1972)

50. Huisman, J.: On Cooperation and Competition II: Institutional Responses to Internationalization, Europeanization, and Globalization. Lemmens Verlag., Bonn, Germany (2005)

51. Salmi, J.: The Challenge of Establishing World-Class Universities. Word Bank, Washington (2009)

52. Murphy-Lejeune, E.: Student Mobility, and Narrative in Europe. Routledge, London (2002)

53. De Vaus, D.: Surveys in Social Research. Routledge, London (2002)

54. EU: Quality Assurance in Higher Education. (2018a) https://eacea.ec.europa.eu/national-policies/eurydice/content/quality-assurance-higher-education-8_en.

55. European Commission: Overview of the Higher Education System in Bosnia and Herzegovina. (2017) DOI 10.2797/689342.

56. Jones, E.: Globalization of Internationalization: Thematic and Regional Reflections on a Traditional Concept.. The International Journal of Higher Education and Democracy 3, 35-54 (2012)

57. United Nations Economic Commission for Europe: Bosnia and Herzegovina Environmental Performance Reviews, Third Review., ECE/CEP/184. (2018)

58. Agency of Herzegovina: Analysis of Student Enrollment for the First Time in the First Year of Study, at Higher Education Institutions, Reports. (2019)

59. Statistics, BiH: Overview of Books., BiH Agency of Statistics., Pregled knjiga (2018)

60. World Bank: Youth Unemployment Indicator. (2018) https://data.worldbank.org/indicator/SL.UEM.1524.ZS.

61. Frontline: Evaluation. Glasgow: SCQF Partnership (2010)

62. National Qualifications Authority of Ireland (NQAI). Response of the NQAI to the Framework Implementation and Impact Study. Dublin: NQAI (2010)

63. Bouder, A., Kirsch, J-1.: The French vocational education and training system: Like an unrecognised prototype? European Journal of Education 42, 4: 503-521 (2007)

64. Keating, J.: The Malaysian Qualifications Framework. Case study. Geneva: ILO (2009)

65. Turcilo Lejla, O.: Youth Study Bosnia and Herzegovina. Friedrich-Ebert-Stiftunge, Berlin (2019)

66. SED: Scottish Education Development: Assessment for All, Edinburgh, HMSO (1977)

67. World Education Forum: Equitable and Inclusive Quality Education and Lifelong Learning for All by 2030. Transforming Lives Through Education., World Education Forum., Republic of Korea (2015) 